\title{
TANGGAP TANAMAN JAGUNG TERHADAP PEMUPUKAN KALIUM DAN PEMBUATAN PARIT PADA LAHAN KERING
}

\section{(Response of Maize to Potassium Fertilization and Making of Furrow on Dry Land)}

\author{
Edy $^{1)}$, Tohari $^{2)}$, Didik Indradewa $^{2)}$, dan Dja'far Shiddieq ${ }^{2)}$ \\ ${ }^{1)}$ Fakultar Pertanian Universitas Muslim Indonesia \\ ${ }^{2)}$ Pascasarjana Fakultas Pertanian Universitas GadjahMada \\ ${ }^{1)}$ Email : nuhungedy63@yahoo.com
}

\begin{abstract}
Water management in rainfed dry land is very important to consider. Limited water on dry land can be pursued with rain harvesting technology among others, by making furrow filled with organic matter in situ. In anticipation of drought stress during the growth period of maize, even the optimum potassium fertilizer make it more survive when low rain fall that the productivity results remain stable. This study aims to determine the response of maize to potassium fertilization and treatment of furrow on the improvement of maize yield on dry land. The research was conducted in the Village of Wareng, sub District of Wonosari, District of Gunung Kidul Province of D.I. Yogyakarta, which takes place from November 2010 - February 2011. The design used is the design of Splite plots, with the main plot is designed in a Latin Square. The main plot is the trench model consists of three standard Furrows: Without the furrow (Control, P0), Furrow (P1), Furrow+organic matter (P2). Potassium fertilization sub plot is comprised of 3 levels: without potassium fertilization (control, K0), $37.5 \mathrm{~kg} \mathrm{KCl.ha-1} \mathrm{(K1)} \mathrm{and} 75$ $\mathrm{kg} \mathrm{KCl.ha-1} \mathrm{(K2).} \mathrm{To} \mathrm{obtain} 9$ combined treatments was repeated 3 times. Corn varieties tested were Bima-2 Bantimurung. The results showed that the combination of furrow+ organic matter and $75 \mathrm{~kg}$ KCl.ha-1 can increase soil moisture between 3-17\%, plant growth rate 35-85\%, water-use efficiency $33 \%$, and yield of corn per hectare $30 \%$.
\end{abstract}

Keywords: Furrow; potassium; maize, dry land

\section{PENDAHULUAN}

Jagung merupakan salah satu tanaman pangan penting dunia, selain gandum dan padi. Selain sebagai sumber karbohidrat, jagung juga ditanam sebagai pakanternak, penghasil minyak dan tepung serta bahan baku industri lainnya (Anonim, 2009). Kebutuhan jagung untuk bahan pangan, pakan dan industri meningkat terus. Oleh karena itu produksi jagung harus ditingkatkan dengan memanfaatkan potensi lahan kering yang tersedia luas dengan teknologi yang tepat guna.

Data Badan Pertanahan Nasional tahun 2005, menunjukkan luas daratan Indonesia sekitar 188 juta hektar, sekitar 75 juta hektar lahan kering yang tersebar di berbagai daerah (Anonim 2007). Hal ini merupakan potensi yang dapat dikembangkan untuk meningkatkan produksi jagung, namun permasalahan lahan kering adalah keterbatasan lengas tanah yang sangat tergantung pada curah hujan, sehingga produktivitas tanaman 
umummya relatif rendah. Di samping itu, $\mathrm{ha}^{-1}$ lebih bertahan pada kondisi cekaman kehilangan air melalui evaporasi dan kekeringan dibandingkan tanpa atau transpirasi tanaman tinggi disebabkan dengan pemupukan kalium kurang dari sistem budidaya yang kurang tepat (Prema chandra dkk., 2008). Panen air hujan in $50 \mathrm{~kg} \mathrm{~K}_{2} 0 . \mathrm{ha}^{-1}$.

Penelitian ini bertujuan untuk situdengan pembuatan Semi-sircular mengetahui pengaruhparit yang diisi bunds yang umum di daerah semi-arid, bahan organik dalam menyediakan lengas half moons, atau demi lunesdi daerah tanah dan efek pemupukan kalium dalam Western Afrika, menunjukkan bahwa peningkatan hasil jagung pada lahan model panen air hujan tersebut hasil kering. tanaman meningkat (Barry and Sonou, 2003).

Selain ketersediaan lahan kering yang relatif luas, hujan yang turun pada setiap tahun dapat pula dipandang sebagai potensi dan anugerah sehingga apabila dikelola dengan baik maka dapat memberikan manfaat terhadap peningkatan produksi tanaman khususnya jagung pada lahan kering. Dalam upayameningkatkan jumlah dan waktu tersedianya air diperlukan pengelolaan air yang tepat antara lain dengan memanen hujan berupa pembuatan parit yang diisi bahan organik dan peningkatan ketahanan tanaman terhadap cekaman kekerigan dengan pemupukan kalium. Hasil penelitian yang dilakukan oleh Mapegau (2006), menunjukkan, tanaman yang diberikan pupuk kalium sebanyak $75-100 \mathrm{~kg} \mathrm{~K}_{2} \mathrm{O}$

\section{METODE PENELITIAN}

Penelitian ini dilakukan di Desa Wareng Kecamatan Wonosari Kabupaten Gunung kidul Propinsi D.I. Yogyakarta di lahan kering. Penelitian dilaksanakan mulai November 2010 sampai dengan Februari 2011. Rancangan yang digunakan adalah Rancangan Petak Terpisah, dengan Petak Utama didesain dalam Bujur Sangkar Latin. Petak utama adalah model Parit terdiri atas 3 taraf: Tanpa parit (Kontrol, $\left.\mathrm{P}_{0}\right)$, Parit $\left(\mathrm{P}_{1}\right)$, Parit diisi bahan organik $\left(\mathrm{P}_{2}\right)$. Anak petak adalah pemupukan kalium terdiri dari 3 taraf : tanpa kalium (kontrol, $\mathrm{K}_{0}$ ), 37,5 kg $\mathrm{KCl}^{-1} \mathrm{ha}^{-1}\left(\mathrm{~K}_{1}\right)$ dan75 kg KCl.ha ${ }^{-1}\left(\mathrm{~K}_{2}\right)$. , diperoleh 9 kombinasi perlakuan diulang 3 kali. Jagung yang diuji adalah varietas Bima-2 Bantimurung.

Parameter yang diamati: 1) Lengas tanah harian, ditentukan dengan metode 
gravimetrik pada kedalaman $20 \mathrm{~cm}$. (mg/m²/minggu), LI: luas lahan atau jarak Pengukuran dilakukan saat tanam dan tanam $\left(\mathrm{m}^{2}\right)$; B: bobot kering tanaman $(\mathrm{g})$; kemudian diulang setiap 2 minggu sekali, $\mathrm{U}$ : umur tanaman (minggu); 1 dan 2 : diamati pada pukul 08.00-09.00, 13.00- pengambilan sample ke-1 dan ke-2 14.00 dan 16.00-17.00 kemudian dihitung dengan umur berbeda-beda menurut untuk menperoleh lengas tanah harian nomer penelitian (Gardner et al., 1991); 3) kemudian dikonversi dari \% ke mm. 2) Efisiensi penggunaan air (EPA), Laju pertumbuhan tanaman (LPT), diukur ditentukan terhdap bobot kering biomas saat tanaman berumur 2-4, 4-8 dan 8- terbentuk (BK) tiap satu satuan jumlah air 12MST, dihitung dengan rumus : LPT $=$ yang diterima per tanaman, dengan 1/LI x $\left(\mathrm{B}_{2}-\mathrm{B}_{1}\right) /\left(\mathrm{U}_{2}-\mathrm{U}_{1}\right)$. dimana LPT persamaan menurut Beets (1982) adalah laju pertumbuhan tanaman dalamSharratt and Denise (2005):

$$
\mathrm{EPA}=\frac{\text { Hasil Tanaman }(\mathrm{mm} / \mathrm{tanaman})}{\text { ET }_{\mathrm{a}} \text { selama Musim Tanam }(\mathrm{mm} / \mathrm{tanaman})}
$$

dimana, $\mathrm{ET}_{\mathrm{a}}=$ evapotraspirasi aktual. 4) Hasil biji jagung per hektar dari masingmasing tanaman dicari dengan menggunakan rumus: $\mathrm{H} / \mathrm{hektar}=(100-$ $\mathrm{ka}) /(100-14) \times \mathrm{b} / \mathrm{l} \times 10$, dimana $: \mathrm{H}=$ hasil biji kering dengan kadar air 14\% (t/ha); 1 = luas petak panen; $b=$ berat biji kering matahari pada petak panen; $\mathrm{ka}=$ berat biji kering matahari ditentukan dengan moisture tester $; 10$ = faktor pengubah dari ton dan dari $\mathrm{m}^{2} \mathrm{ke}$ ha (Hartati, 1998).

Pelaksanaan penelitian dimulai dari pembuatan parit berukuran, lebar 30 $\mathrm{cm}$, dalam $40 \mathrm{~cm}$, dan panjang parit disesuaikan dengan jumlah plot perlakuan parit. Parit hanya berada pada 2 sisi plot, tidak mengelilingi plot. Pada perlakuan $\mathrm{P}_{2}$ parit diisi dengan bahan organik berupa residu tanaman yang ada di sekitar percobaan. Setelah persiapan selesai, maka penanaman jagung dan kacang hijau siap dilakukan. Pemupukan Urea dan SP36 dilakukan dengan dosis berdasarkan rekomendasi Dinas pertanian yaitu 300 Urea ha $^{-1}, 75 \mathrm{~kg} \mathrm{KCl} \mathrm{ha}{ }^{-1}$ dan $100 \mathrm{~kg} \mathrm{SP}-$ $36 \mathrm{ha}^{-1}$. Pupuk urea diberikan dua kali masing-masing setengah bagian, yaitu 15 hari setelah tanam dan saat tanaman berumur 40 hari setelah tanam. SP-36 dan $\mathrm{KCl}$ diberikan bersamaan pemupukan urea pertama dengan cara tugal sekitar $15 \mathrm{~cm}$ dari tanaman. Lubang tanam diisi pupuk 

Kering

organik petrokimia sebanyak 100 gram dapat dilihat pada umur tanaman 4, 10 dan atau setara dengan 2,5 ton per hektar. 12 minggu. Takaran kalium yang cukup Jarak tanam jagung $130 \mathrm{~cm}$ x $40 \mathrm{~cm}$ dapat meningkatkan pertumbuhan dengan jumlah populasi per lubang 2 tanaman sehingga secara tidak langsung tanaman. Varietas kacang hijau yang dapat menahan aliran permukaan lebih digunakan adalah varietas Murai, baik sehingga meningkatkan infiltrasi air menggunakan jarak tanam $30 \mathrm{~cm}$ x $40 \mathrm{~cm}$. tanah. Pemberian bahan organik di dalam

\section{HASIL DAN PEMBAHASAN}

1. Lengas Tanah

Pada Tabel 1 menunjukkan lengas tanah tidak dipengaruhi oleh interaksi antara model parit dengan pemupukan kalium. Secara umum, pemupukan kalium tidak berpengaruh terhadap peningkatan lengas tanah kecuali

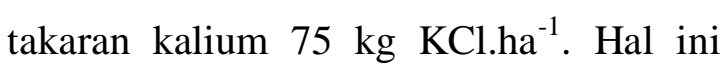
parit pada lahan meningkatkan lengas tanah dibandingkan tanpa parit, terutama pada umur pengamatan $4,8,10$, dan 12 minggu, namun tidak berbeda dengan pemberian parit kecuali umur 10 minggu. Hal ini sejalan dengan penelitian Jones and Stewart (1990), penggunaan dam parit dari tanah meningkatkan penahanan aliran permukaan dan meningkatkan infiltrasi. 
Edy : Tanggap Tanaman Jagung terhadap Pemupukan Kalium dan Pembuatan Parit pada Lahan Kering

Tabel 1. Lengas tanah harian pertanaman jagung pada perlakuan model parit dan pemupukan kalium ( $\mathrm{mm} /$ hari/plot)

\begin{tabular}{|c|c|c|c|c|}
\hline \multicolumn{5}{|c|}{ Lengas tanah pertanaman jagung awal pada umur 4 minggu } \\
\hline \multirow{2}{*}{ Model parit } & \multicolumn{3}{|c|}{ Takaran pupuk K ( kg KCl/ha) } & \multirow{2}{*}{ Rerata } \\
\hline & 0 & 37,5 & 75 & \\
\hline Tanpa parit & 6.30 & 6.47 & 6.48 & \multirow{3}{*}{$\begin{array}{l}6.42 \mathrm{~b} \\
6.64 \mathrm{ab} \\
6.88 \mathrm{a}^{6}\end{array}$} \\
\hline Parit & 6.52 & 6.60 & 6.79 & \\
\hline Parit+bahan organik & 6.79 & 6.86 & 7.01 & \\
\hline \multirow{2}{*}{$\begin{array}{r}\text { Rerata } \\
\text { L }\end{array}$} & $6.53 \mathrm{~b}$ & $6.64 \mathrm{ab}$ & $6.76 \mathrm{a}$ & \multirow[t]{2}{*}{$(-)$} \\
\hline & anaman & ing awal p & Imur $8 \mathrm{~min}$ & \\
\hline \multirow{2}{*}{ Model parit } & \multicolumn{3}{|c|}{ Takaran pupuk K ( kg KCl/ha) } & \multirow{2}{*}{ Rerata } \\
\hline & 0 & 37,5 & 75 & \\
\hline Tanpa parit & 6.59 & 6.57 & 6.59 & $6.59 \mathrm{~b}$ \\
\hline Parit & 6.69 & 6.76 & 6.69 & $6.71 \mathrm{ab}$ \\
\hline Parit+bahan organik & 6.66 & 6.81 & 6.85 & $6.77 \mathrm{a}$ \\
\hline Rerata & $6.65 \mathrm{a}$ & $6.71 \mathrm{a}$ & $6.71 \mathrm{a}$ & $(-)$ \\
\hline \multicolumn{5}{|c|}{ Lengas tanah pertanaman jagung awal pada umur 10 minggu } \\
\hline \multirow{2}{*}{ Model parit } & \multicolumn{3}{|c|}{ Takaran pupuk K ( kg KCl/ha) } & \multirow{2}{*}{ Rerata } \\
\hline & 0 & 37,5 & 75 & \\
\hline Tanpa parit & 5.00 & 5.03 & 4.96 & $4.99 \mathrm{c}$ \\
\hline Parit & 5.29 & 5.31 & 5.54 & $5.38 \mathrm{~b}$ \\
\hline Parit+bahan organik & 5.50 & 5.71 & 5.80 & $5.67 \mathrm{a}$ \\
\hline Rerata & $5.26 \mathrm{~b}$ & $5.35 \mathrm{ab}$ & $5.43 \mathrm{a}$ & $(-)$ \\
\hline \multicolumn{5}{|c|}{ Lengas tanah pertanaman jagung awal pada umur 12 minggu } \\
\hline \multirow{2}{*}{ Model parit } & \multicolumn{3}{|c|}{ Takaran pupuk K ( kg KCl/ha) } & \multirow{2}{*}{ Rerata } \\
\hline & 0 & 37,5 & 75 & \\
\hline Tanpa parit & 4.83 & 4.87 & 4.87 & $4.86 b$ \\
\hline Parit & 5.25 & 5.31 & 5.42 & $5.33 \mathrm{a}$ \\
\hline Parit+bahan organik & 5.47 & 5.48 & 5.74 & $5.56 \mathrm{a}$ \\
\hline Rerata & $5.18 \mathrm{~b}$ & $5.22 \mathrm{~b}$ & $5.34 \mathrm{a}$ & $(-)$ \\
\hline
\end{tabular}

Keterangan:

Angka yang diikuti oleh huruf yang sama pada baris dan kolom berbeda tidak nyata pada taraf uji

Duncan $a_{0.05}$. (-) : tidak ada interaksi; (+): ada interaksi

Pemberian kalium tidak aplikasi $\mathrm{K}$ memberikan respon terhadap berpengaruh nyata terhadap lengas tanah, hasil, terutama mempertinggi namun ada kecenderungan makin tinggi pertumbuhan akar (Menggel dan Kirkby, takaran kalium yang diberikan makin 1987). Hal ini sejalan dengan penelitian tinggi lengas tanah. Respon tanaman yang menyatakan bahwa pengaruh utama terhadap stress lengas dan suhu bahan organik adalah memperlambat dipengaruhi oleh status $\mathrm{K}$ dalam tanaman. aliran permukaan, meningkatkan infiltrasi, Di bawah kondisi kandungan lengas dan memantapkan agregat tanah (Arsyad, rendah ketika ketersediaan K rendah, 2000 dalam Dariah dkk., 2006). 

Kering

\section{Laju Pertumbuhan Tanaman (LPT)}

Laju pertumbuhan tanaman umur 2-4 minggu pada Tabel 2 menunjukkan terjadi interaksi antara model parit dan pemupukan kalium. Pemupukan kalium tidak berpengaruh terhadap LPT pada areal tanpa parit. Pemupukan $37,5 \mathrm{~kg}$ $\mathrm{KCl} . \mathrm{ha}^{-1}$ tidak meningkatkan LPT saat tanaman masih muda, umur antara 2-4 minggu, namun dengan pemupukan $75 \mathrm{~kg}$ $\mathrm{KCl} \cdot \mathrm{ha}^{-1}$ meningkatkan LPT dibandingkan tanpa pemupukan kalium. Pemberian model parit tidak berpengaruh terhadap LPT apabila tanaman tidak dipupuk kalium. Pemberian parit pada areal tidak meningkatkan LPT namun pemberian bahan organik di dalam parit berumur antara 4-6 minggu dan 6-8 meningkatkan LPT pada pemupukan 37,5 minggu.

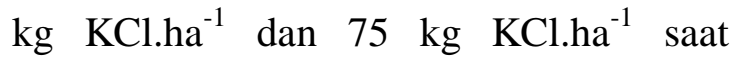
tanaman berumur antara 2-4 minggu. Saat tanaman berumur antara 4-6 minggu dan 6-8 minggu tidak ada pengaruh interaksi antara model parit dan pemupukan kalium. Pemupukan kalium meningkatkan LPT dan semakin meningkat dengan makin meningkatnya takaran kalium yang diberikan. Pemberian parit dan bahan organik di dalam paritmeningkatkan LPT dan semakin meningkat dengan makin meningkatnya takaran pupuk kalium yang diberikan. Pemberian parit dan bahan organik di dalam parit pada areal dibandingkantanpa parit saat tanaman pertanaman meningkatkan LPT 
Edy : Tanggap Tanaman Jagung terhadap Pemupukan Kalium dan Pembuatan Parit pada Lahan Kering

Tabel 2. Laju pertumbuhan tanaman jagung pada perlakuan model parit dan takaran pupuk kalium $\left(\mathrm{g} / \mathrm{m}^{2} /\right.$ minggu $)$

\begin{tabular}{|c|c|c|c|c|}
\hline \multicolumn{5}{|c|}{ Laju pertumbuhan tanaman pada umur 2-4 minggu } \\
\hline Model & \multicolumn{3}{|c|}{ Takaran pupuk $\mathrm{K}(\mathrm{kg} \mathrm{KCl} / \mathrm{ha})$} & \multirow[b]{2}{*}{ Rerata } \\
\hline Parit & 0 & 37,5 & 75 & \\
\hline Tanpa parit & $48,54 \mathrm{de}$ & $44,04 \mathrm{e}$ & $48,07 \mathrm{de}$ & 46,88 \\
\hline Parit & $42,99 \mathrm{e}$ & $50,53 \mathrm{cde}$ & $55,27 \mathrm{bcd}$ & 49,60 \\
\hline Parit+bahan organik & $57,95 \mathrm{abc}$ & $63,00 \mathrm{ab}$ & $65,00 \mathrm{a}$ & 61,98 \\
\hline Rerata & 49,83 & 52,52 & $\overline{56,11}$ & $(+)$ \\
\hline \multicolumn{5}{|c|}{ Laju pertumbuhan tanaman pada umur 4-6 minggu } \\
\hline Model & \multicolumn{3}{|c|}{ Takaran pupuk K ( kg KCl/ha) } & \\
\hline Parit & 0 & 37,5 & 75 & Rerata \\
\hline Tanpa parit & 43,06 & 51,71 & 53,75 & $49,50 \mathrm{~b}$ \\
\hline Parit & 56,80 & 67,01 & 78,16 & $67,32 \mathrm{ab}$ \\
\hline Parit+bahan organik & 51,41 & 71,45 & 83,04 & $68,63 \mathrm{a}$ \\
\hline Rerata & $50,42 \mathrm{c}$ & $63,39 \mathrm{~b}$ & $71,65 \mathrm{a}$ & $(-)$ \\
\hline \multicolumn{5}{|c|}{ Laju pertumbuhan tanaman pada umur 6-8 minggu } \\
\hline Model & \multicolumn{3}{|c|}{ Takaran pupuk K ( kg KCl/ha) } & \\
\hline Parit & 0 & 37,5 & 75 & Rerata \\
\hline Tanpa parit & 83,75 & 93,58 & 117,14 & $98,16 \mathrm{~b}$ \\
\hline Parit & 81,34 & 112,48 & 145,06 & $112,96 \mathrm{a}$ \\
\hline Parit+bahan organik & 93,81 & 156,44 & 168,40 & $139,55 \mathrm{a}$ \\
\hline Rerata & $86,30 \mathrm{c}$ & $120,83 \mathrm{~b}$ & $143,54 \mathrm{a}$ & $(-)$ \\
\hline \multicolumn{5}{|c|}{ Laju pertumbuhan tanaman pada umur 8-12 minggu } \\
\hline Model & \multicolumn{3}{|c|}{ Takaran pupuk K ( kg KCl/ha) } & \\
\hline Parit & 0 & 37,5 & 75 & Rerata \\
\hline Tanpa parit & $-8,90 \mathrm{~b}$ & $-2,68 \mathrm{a}$ & $-2,64 a$ & $-4,74$ \\
\hline Parit & $-4,87 \mathrm{a}$ & $-3,82 a$ & $-2,08 \mathrm{a}$ & $-3,59$ \\
\hline Parit+bahan organik & $-2,08 \mathrm{a}$ & $-1,33 a$ & $-1,06 a$ & $-1,49$ \\
\hline Rerata & $-5,28$ & $-2,61$ & $-1,93$ & $(+)$ \\
\hline
\end{tabular}

Keterangan:

Angka yang diikuti oleh huruf yang sama pada baris dan kolom berbeda tidak nyata pada taraf uji Duncan $\mathrm{a}_{0,05}$

Laju pertumbuhan tanaman umur dibandingkan dengan tanaman yang 8-12 minggu terjadi interaksi antara dipupuk kalium pada areal tanpa parit. model parit dan takaran pupuk kalium. Tingkat penurunan LPT lebih tinggi pada Pemupukan kalium tidak berpengaruh areal tanpa parit dibandingkan areal yang terhadap tingkat penurunan LPT pada diberi parit dan areal yang diberi bahan areal yang diberi parit dan areal yang organik di dalam parit. Tingkat penurunan diberi bahan organik di dalam parit, LPT tidak dipengaruhi oleh model parit namun tanpa pemupukan kalium dapat pada tanaman yang dipupuk 37,5 $\mathrm{kg}$ meningkatkan penurunan LPT $\mathrm{KCl}^{-h^{-1}}$ dan $75 \mathrm{~kg} \mathrm{KCl} \cdot \mathrm{Ka}^{-1}$. Aktivitas 
fotosintesis menurun dengan dibandingkan tanpa pemupukan kalium. berkurangnya kandungan lengas tanah, EPA meningkat pada areal yang diberi karena terjadinya penutupan stomata. parit dan semakin meningkat pada areal Fitter dan Hay (1994), bahwa laju yang diberi bahan organik di dalam parit pertumbuhan sel tanaman dan efisiensi dibandingkan areal tanpa parit. Hal ini proses fisiologisnya mencapai tingkat sejalan dengan hasil penelitian Prabowo tertinggi bila sel-sel berada pada turgor dkk. (2004) bahwa untuk hasil jagung maksimum. Turgor berpengaruh terhadap yang dicapai oleh irigasi tetesse banyak pembesaran dan pembengkakan sel untuk $6600 \mathrm{~kg} / \mathrm{ha} / \mathrm{musim}$ maka nilai proses perbanyakan sel (Salisbury dan produktivitasnya adalah 1,96 kg/m3-air. Ross, 1995). Kalium berperan dalam Produktivitas air untuk irigasi curah pengaturan tekanan osmotik dan turgor adalah $1,93 \mathrm{~kg} / \mathrm{m}^{3}$-air. Dari nilai tersebut tanaman. Marchner (1986); Menggel and terlihat bahwa setiap meter kubik volume Kirkby (1982), menyatakan bahwa kalium air yang diberikan ketanaman mampu berperan pada tahap sintesis protein menghasilkan biji jagung seberat 1,96 kg, karenalajuperubahan $\mathrm{N}$ dansintesis protein dan $1,96 \mathrm{~kg} \quad$ (biji) mempunyai arti pada tanaman tergantung pada kandungan ekonomis dari aspek input maupun output kaliumnya.

\section{Efisiensi Penggunaan Air (EPA)}

Tidak ada pengaruh interaksi antara model parit dan pemupukan kalium. Efisiensi penggunaan air pada Tabel 3 menunjukkan pemupukan kalium $37,5 \mathrm{~kg} \mathrm{KCl} \cdot \mathrm{ha}^{-1}$ meningkatkan EPA dan produksi. Nilai produktivitas air juga menunjukkan marjinalitas penambahan air, yaitu nisbah kenaikan hasil terhadap kenaikan laju evapotranspirasi akibat adanya penambahan air irigasi. Pada tanaman padi untuk menghasilkan $1 \mathrm{~kg}$ gabah diperlukan 5000 liter air atau $5 \mathrm{~m}^{3}$ semakin meningkat dengan makin air (IRRI, 1999). meningkatnya takaran kalium 
Edy : Tanggap Tanaman Jagung terhadap Pemupukan Kalium dan Pembuatan Parit pada Lahan Kering

Tabel 3. Efisiensi penggunaan air tanaman jagung pada perlakuan modelparit dan takara pupuk kalium $(\mathrm{g} / \mathrm{mm})$

\begin{tabular}{lccccc}
\hline \multirow{2}{*}{$\begin{array}{l}\text { Model } \\
\text { Parit }\end{array}$} & \multicolumn{2}{c}{ Takaran pupuk K ( kg KCl/ha) } & \multirow{2}{*}{ Rerata } \\
\cline { 2 - 4 } \multicolumn{1}{c}{ Tanpa parit } & 0 & 37,5 & 75 & $0.69 \mathrm{c}$ \\
Parit & 0.65 & 0.68 & 0.75 & $0.82 \mathrm{~b}$ \\
Parit+bahan organik & 0.68 & 0.81 & 0.96 & $0.92 \mathrm{a}$ \\
\hline \hline \multicolumn{2}{c}{ Rerata } & 0.77 & 1.00 & 1.00 & $(-)$ \\
\hline \hline
\end{tabular}

Keterangan:

Angka yang diikuti oleh huruf yang sama pada baris dan kolom berbeda tidak nyata pada taraf uji Duncan $\mathrm{a}_{0.05}$

(+): terjadi interaksi; (-): tidak terjadi interaksi

4. Berat biji pipilan kering per hektar

Ada pengaruh interaksi antara model parit dan pemupukan kalium. Pemupukan kalium 37,5 kg KCl.ha ${ }^{-1}$ belum meningkatkan berat biji per hektar namun dengan pemupukan kalium $75 \mathrm{~kg}$ $\mathrm{KCl}^{-h^{-1}}$ berat biji per plot meningkat dibandingkan tanpa pemupukan kalium pada areal yang tidak diberi parit. Pemupukan kalium 37,5 kg KCl.ha ${ }^{-1}$ dan $75 \mathrm{~kg} \mathrm{KCl} . \mathrm{ha}^{-1}$ pengaruhnya sama dalam meningkatkan berat biji per hektar dibandingkan tanpa pemupukan kalium pada areal yang diberi parit dan bahan organik di dalam parit. Pemberian parit pada areal tidak meningkatkan berat biji per hektar dibandingkan tanpa parit namun pemberian bahan organik di dalam parit meningkatkan berat biji per hektar pada tanaman yang tidak dipupuk kalium. Pemberian parit pada areal meningkatkan berat biji per hektar dan semakin meningkat dengan pemberian bahan organik di dalam parit dibandingkan tanpa parit pada pemupukan $37,5 \mathrm{~kg} \mathrm{KCl} \cdot \mathrm{ha}^{-1}$ maupun $75 \mathrm{~kg} \mathrm{KCl.ha}{ }^{-1}$.

Tabel 4. Berat biji per hektar jagung pada perlakuan model parit dan takaran pupuk kalium (t)

\begin{tabular}{lccccc}
\hline \multirow{2}{*}{$\begin{array}{c}\text { Model } \\
\text { Parit }\end{array}$} & \multicolumn{4}{c}{ Takaran pupuk K ( kg KCl/ha) } & \\
\cline { 3 - 5 } & & 0 & 37,5 & 75 & Rerata \\
\hline Tanpa parit & $4,22 \mathrm{f}$ & $4,31 \mathrm{f}$ & $5,18 \mathrm{de}$ & 4,57 \\
Parit & $4,62 \mathrm{ef}$ & $5,70 \mathrm{~cd}$ & $6,17 \mathrm{bc}$ & 5,50 \\
Parit+bahan organik & $4,99 \mathrm{e}$ & $6,35 \mathrm{ab}$ & $6,76 \mathrm{a}$ & 6,03 \\
\hline \multicolumn{1}{c}{ Rerata } & 4,61 & 5,45 & 6,04 & $(+)$ \\
\hline \hline
\end{tabular}

Keterangan:

Angka yang diikuti oleh huruf yang sama pada baris dan kolom berbeda tidak nyata pada taraf uji

Duncan $\mathrm{a}_{0,05}$

$(+)$ : terjadi interaksi 
Harnowo (1993) mengemukakan

bahwa cekaman air menghambat fotosintesis dan distribusi asimilat kedalam organ reproduktif. Sebelumnya Ritche (1980) menemukan bahwa proses pengisian biji dan translokasi fotosintat sangat sensitive terhadap cekaman air. Karena itu dapat mengurangi bobot biji kering. Pada daerah tropis, kondisi cekaman kekeringan mengakibatkan penurunan hasil jagung sekitar $17-60 \%$ (Monneveux et al., 2005). Grimme (1985), menyatakan, apabila tanah dalam kondisi cukup air maka ketersediaan $\mathrm{K}$ akan lebih banyak bagi tanaman. Pemupukan K dapat meningkatkan ketersediaan dan penyerapan $\mathrm{K}$ bagit anaman. Kalium dapat meningkatkan penyerapan, translokasi dan penggunaan $\mathrm{N}$ dan senyawa $\mathrm{N}$ oleh biji tanaman (Pretty, 1985).

\section{KESIMPULAN DAN SARAN}

Berdasarkan hasil penelitian ini maka dapat disimpulkan bahwa:

Penggunaan parit yang diisi bahan organic dan $75 \mathrm{~kg} \mathrm{KCl} . \mathrm{ha}^{-1}$ meningkatkan lengas tanah, laju pertumbuhan tanaman, efisiensi penggunaan air dan hasil biji jagung per hektar.
Berdasarkan hasil penelitian ini disarankan: menggunakan parit berisi bahan organik in situ untuk lahan kering tadah hujan terutama daerah tanpa irigasi, dan tetap menggunakan pupuk $\mathrm{N}, \mathrm{P}$ dan K. yang tepat.

\section{Ucapan Terima Kasih}

Ucapan terima kasih disampaikan kepada DP2M DIKTI yang telah membantu sebagian pendanaan penelitian disertasi penulis dalam bentuk Hibah Penelitian Disertasi Doktor.

\section{DAFTAR PUSTAKA}

Anonim, 2007. Galur Harapan baru. Informasi Ilmiah Populer. Balai Penelitian Tanaman Serealia, Maros, Sulawesi Selatan.

Anonim, 2009. Ensiklopedia Jagung. Online:

http://id.wikipedia.org/wiki/Jagung . Diakses: 12 Mei 2009

Barry, B. and M. Sonou, 2003. Best practices in rainfed agriculture in West Africa, Proceedings of the Symposium and Workshop on Water Conservation Technologies for Sustainable Dryland Agriculture in Sub-Saharan Africa Bloemfontein, South Africa, April 8-11, 2003, ARC-Institute for Soil, Climate and Water, Pretoria, South Africa (2003), pp. 60-74.

Dariah, A., H. Subagyo, Chendy Tafakresnanto, dan Setiari Marwanto, 2006. Kepekaan Tanah Terhadap Erosi. Pusat Penelitian 
dan Pengembangan Tanah dan Agroklimat, Bogor.

Fitter, A.H. dan R.K.H. Hay, 1994. Fisiologi Lingkungan Tanaman. Terjemahan Sri Andani dan E.D. Purbayanti. Gadjahmada University Press. Yogyakarta. 421 h.

Gardner, F.P., R.B. Pearce, R.L. Mitchell, 1991. Fisiologi Tanaman Budidaya (diterjemahkan Herawati Susilo). Penerbit Universitas Indonesia, Jakarta.

Grimme, H., 1985. The Dinamics of Potassium in The Soil-Plant System. Proceedings of the 19th Colloquium of The International Potash Institute Held in Bangkok. Thailand. P:127-150.

Harnowo, D, 1993. Respons Tanaman Kedelai (Glycine max L. Merrill) terhadap Pemupukan Kalium dan Cekaman Kekeringan pada Fase Reproduktif. IPB. Bogor.

Jones, O.R., and B.A. Stewart. 1990. Basin Tillage. Soil Tillage Res. 18:249-265.

Mapegau, M., 2006 .Pengaruh Pemupukan Kalium Terhadap Toleransi Fisiologi Tanaman Jagung Kultivar Arjuna pada Kondisi Cekaman Air., Agrivigor, Vol 5 (no. 3), Abstract.

Marschner, H., 1086. Mineral Nutrition of Higher Plants. Academic Press Inc. London. 647p.

Mengel, K., dan E. A. Kirkby. 1987. Principles of Plant Nutrition. Pub.
Int. Potash Institute Warbladen. Bem Switzerland. 687p.

Prabowo, A. , A. Prabowo, A. Hendriadi dan M. J. Tjaturetna, 2004. Pengelolaan Irigasi Tanaman Jagung Lahan Kering : Aplikasi Irigasi Tetes. Makalah ini disampaikan pada seminar "Peran Strategis Mekanisasi Pertanian DalamP engembangan AgroindustriJ agung", tanggal 20 Desember 2004 di Badan Litbang Pertanian, Jakarta.

Premachandra, G.S. , H.Saneoka, K.FujitaS.Ogata, 2008. Water Stress and Potassium Fertilization in Field Grown Maize (Zea mays L.): Effects on Leaf Water Relations and Leaf Rolling. Journal Agr. And Crop Sci, Vol.170, P:195-201.

Pretty, K.M., 1980. Potassium and Crop Quality. Published by Potash and Phosphate Institute. Atlanta. $\mathrm{P}: 165-178$.

Ritche, J. T. 1980 Climate and soil water,In Moving up the yield curve.Advace and obstacle, Spec. Publ. No.39.p: 1-23.

Salisbury, F.B. dan Ross, C.W. 1995. Fisiologi Tumbuhan II. Ed. 4. Terjemahan: D.R. Lukman danS umaryono. Penerbit ITB. Bandung. 173 hal.

Sharratt, B.S dan Denise A.M, 2005. Microclimatic and Rooting Characteristics of Narrow - Row versus Conventional - Row Corn. Agr. J.97 : 1129 - 1135. 